INTERNATIONAL JOURNAL OF RESEARCHES IN BIOSCIENCES, AGRICULTURE AND TECHNOLOGY (C) VISHWASHANTI MULTIPURPOSE SOCIETY (Global Peace Multipurpose Society) R. No. MH-659/13(N) www.vmsindia.org

\title{
EFFECT OF ORGANIC DUST ON HEALTH OF SERICULTURE WORKERS, DAWADIPAR, DISTRICT BHANDARA, M.S.
}

\author{
Sharyu.V.Ghonmode \\ Department of Zoology, S.S.E.S.Amt's Science College, \\ Congress Nagar,Nagpur University, \\ Nagpur-440012 (M.S.) \\ sharyu.ghonmode@gmail.com
}

\begin{abstract}
:
Sericulture is well-established agro-cottage industry under informal sector. Poor, rural and tribal people of India gets employment via sericulture to generates nearly 25,000 crores of which Rs. 2500 crores are generated by foreign exchange by employing 5 lakh rearers and rest of them are reelers, twisters, weavers, printers etc. Sericulture involves hatching of eggs up to reeling. Although life cycle of silkworm is eco-friendly but there are several health hazards in which the workers are exposed to various health problems due to lack of education, poor nutrition, and unawareness about the hazards of their occupation. Silk manufacturing involves cultivation of mulberry and nonmulberry food plants, rearing of silkworms, grainages, reeling of filaments, twisting, weaving, printing and dyeing. It has been observed that women are more prone to the health hazards as compared to men. The organic dust comes from hay, grain, fuel chips, straw, and livestock. It also includes molds, pollens, bacteria, pesticides, chemicals, feed and bedding particles, and animal particles including hair, feathers, and droppings. Its long term exposure is toxic may cause asthma and lung cancer. It is therefore very important to check the health, safety, welfare and protection of the workers to reduce the illness and problems.
\end{abstract}

Key words: Silk industry, health problems, asthma, safety measures, organic dust.

\section{INTRODUCTION:}

Sericulture or silk farming is an agro based cottage industry where it involves cultivation of silkworm to produce silk. Several species of silkworm like Bombyx mori, Antheraea mylitta are used to produce silk like mulberry and tassar. Women and men both get the employment in this sector. Sericulture involves cultivation of mulberry, tasar plants, rearing of silkworm, reeling and other post- cocoon activities such as twisting, dyeing, weaving, printing and finishing. Among the three natural fibers i.e, silk, wool and cotton, silk is considered as the "Queen of Textiles". India produces all four different types of silk varieties. Following processes are involved like Mulberry and non-mulberry food plant cultivation, Silkworm rearing, Production of egg in grainages, Silk filament reeling, Twisting, Weaving, Printing, Dyeing.

The larvae hatch from the eggs and feeds on the food plants. They undergo various developmental stages from Ist Instar larvae to
VthInstar larvae. After this the $V^{\text {th }}$ instar larvae starts oozing out a secretion from the mouth of the silkworm called as spinneret. After coming in contact with surrounding environment the oozed out secretion solidifies and forms a soft covering called as cocoon. This cocoon protects the silkworm pupae from adverse conditions of climate. The next process is reeling where the cocoons are boiled in hot water so that the silk thread wrapped around the cocoon gets loosened and the thread comes out of cocoon. This thread is reeled. After reeling the thread is weaved. After this the silk thread is dyed or printed accordingly. Various other processes are done like the smoothening, polishing, lustering and removing wrinkles from the thread which requires human resource.

Sericulture farming is an eco and environmental friendly process. Still the workers have to face lot of health hazards which may be life threatening. Textile industries in abroad have reported respiratory problems but there is less 
study on the respiratory problem in India (Murlidhar V. et al.,1995); Mathur N. et al.,1993; Jaiswal A., 2004).Women are more prone to such diseases (Nilvarangkul K,et.al.,2006). Theindustry has been handling with chemicals which may be fatal to the workers and farmers life. Thousands of sericulture workers and the risk associated with this industry are very high due to lack of education, not aware about the health hazards associated with their occupation, backwardness in their daily hygiene, poor sanitation, and poor nutrition (Wang, X. R., et.al. 2003).

\section{MATERIAL AND METHODS:}

\section{Area of study-}

This study was carried out in the village Dawadipar. Dawadipar is a small village located in Mohadi Taluka of Bhandara district, Maharashtra. It is situated $8 \mathrm{~km}$ away from Bhandara. The tasar silkworm, Antheraea mylitta (D) "Dabha Race" is regularly cropped since last 40 years at the Central Tasar Research and Training Institute (CTRTI) and Basic Seed Multiplication and Training Centre (BSMTC) Dawadipar, Bhandara (Maharashtra State), India. In India, the species A.mylitta (D) occurs in 25 ecotypes or races (Jolly, M.S., et.al., 1979).

Total population of Dawadipar is 1,530 . Male Population is $794 \&$ female Population is 736. 110 were engaged in work activities. 89.09 $\%$ of workers describe their work as Main Work (minimum half yearly income) while $10.91 \%$ were involved in Marginal activity providing livelihood for less than half yearly income. Of 110 workers engaged in Main Work, 17 were cultivators (owner or co-owner) while 59 were Agricultural labourers. Out of 110 workers 64 are male and 46 are female workers. Data was collected by visiting houses of every worker and asking the questions based on the questionnaire prepared.

\section{RESULT AND DISCUSSION:}

Sericulture is an agro-cottage industry under informal sector. Silk manufacturing involves several steps. Workers are exposed to aerosols generated when silkworm cocoons are placed in boiling water to dissolve 'sericin' from outer layer. Silk thread reeled from cocoon is rolled, twisted into yarn and dyed before weaving. Workers employed in grainages where cocoons are stored and in cocoon trading centres are exposed to epithelial dust from silkworm moths and cocoons (Chandrasekar S.,2018). Workers in farms producing mulberry leaves for silkworm rearing centers and dyeing units are also at risk of developing asthma as they are exposed to pesticides, disinfectants and chemical dyes. Previous studies showed that some sericulture workers develop sensitization to silkworm allergens over a period. Occupational Asthma in employees is attributable to exposure to biological or inorganic agents at workplace. Objective of this study was to detect prevalence of asthma among sericulture workers, as many cases of asthma were observed in places where there are many sericulture industries in South India. Out of 110 workers 64 are male and 46 are female workers. Data was collected by visiting houses of every worker and asking the questions based on the questionnaire prepared. Mechanisation and installation of barriers to prevent manual handling and aerosol exposure is recommended, but not possible being a cottage industry with many small filature units. Quitting job is not practical due to workers financial status. Hence awareness programmes on prevention, personal protective equipments and early treatment is required (Chandrasekar S., 2018).

Grainages are the centers where disease free laying of eggs known as industrial seeds is produced. In grainages different processes are carried out like-cocoon preservation, emergence of moth, coupling and decoupling and oviposition. Lot of workers supplies this seeds to various government and private rearing centers. Workers are in constant touch with the adult moth the wings of which triggers asthma and many more respiratory diseases along with diminished lung 
function and chest tightness. Male silkworm caterpillars release wing and body scales as they flutter during copulation causes allergy(Venkatappa.B.et.al. 2005).

Unwinding of the weaved thread from the cocoon is called as reeling. Prior to reeling there are various process like cooking, boiling, deflossing and riddling. The reeling industry is highly exposed to dust and if inhaled for longer time cause lung infections, chronic bronchitis, cough and asthma (Beckett WS., 2000).Asthma has also been observed in children working in silk industry (Wen, CM, et.al., 1999). It also leads to swelling of face, skin allergies and inflammation of eyes. These diseases are commonly found in reeling industry or during the spooling of the silk thread, as the silk allergens are continuously exposed and released in the air (Harindranath N, et.al., 1985). The sericulture workers are at risk of developing asthma and continued exposure to allergens can progress to chronic obstructive pulmonary disease in some workers.

Sericulture Industry should provide following Safety measures -

Safety of the worker is the priority of the employer. His prime and most important duty is to take care of his workers health, welfare and protection as the health, safety are directly associated with the output or profit of the employer. Thus following safety measures are to be taken in the sericulture industry:

1) Good ventilation of rearing house,

2) Health check-up camps should be organised regularly,

3) Glasses, gloves and masks should be provided as an when required during the process,

4) All the accessories used should be clean and hygienic condition should be maintained for disease free environment.

5) Ventilation should be provided in grainage and dyeing chambers for the removal of toxic fumes,
6) Lab coats, masks and full hand and foot gloves or personal protective equipments (PPE) should be used to avoid the moth scales allergens in grainages.

7) Exhaust fans should be provided in each and every rearing, reeling, weaving, dyeing, printing room.

8) Emergency eye washing fountains and shower facility should be provided so that the worker can use the facility as an when required to maintain the personal hygiene and to remove any of the chemical to which the body has come in contact.

9) Health education and medical supervision is essential for the workers,

10) Prevention is primarily a matter of dust control, information, and medical surveillance. In the future, specific agents like bacterial endotoxins should be controlled.

\section{CONCLUSION:}

Silk is considered as the most elegant textile in the world with natural soft lusture, and inherent affinity for dyes,light weight and its high durability. Itprovides employment opportunities for millions. Lot of farmers get employment based on both farm and non-farm related opportunities. Large number of employment refers to large number of occupational hazards. The workers are more prone to disorders associated with silk industry. The disease can be prevented by taking proper precautions and necessary facilities to be provided by the employer. It is therefore very important to organize awareness camps among the sericulture farmers, health check-up camps, personal hygiene awareness and cleanliness of the instruments to be used so that the risk of suffering from these diseases are minimized.

\section{REFERENCES:}

Beckett WS. Occupational respiratory disease.The New EnglandJournal of Medicine. 2000; 342(6):406-413. 
Chandrasekar S.(2018).Asthma in sericulture workers due to organic dust exposure. Occupational and Environmental Medicine 75(Suppl 2):A472.1-A472 . April 2018.

Harindranath N, Prakash O, Subba Rao PV. Prevalence of occupational asthma in silk filatures. Ann Allergy 1985;55:5115

Jaiswal A., 2004. Respiratory Efficiency as affected by exposure to textile dusthealth status evaluation of textile workers of district Varanasi, Utter Pradesh. Gene, Environment and Health, Delhi, 135-162.

Jolly, M.S., Sen, S.K., Sonwalkar, T.N. and Prasad, G.K. (1979). Non-mulberry silks.FAO.Agric.Servic.Bull.29:1-178.

Murlidhar V, Murlidhar VJ, Kanhere V., 1995. Byssinosis in a Bombay textile mill. Nat. Med J India; 8:204-207.

Mathur N, Gupta B.N., Rastogi S.K., 1993. The multivariate analysis of byssinosis risk assessment.Indian $\mathrm{J}$ Chest Dis Allied Sci: 35; 185-190.
Nilvarangkul K, Wongprom J, Tumnong C., 2006. Strengething the self-care of women in informal sector: Local fabric weaving in KhonKaen, (Phase I), Industrial Health; 44: 101-107.

Venkatappa. B., A. N. Chandrakala., P. Anuradha and P. Chatrappa., 2005.Evaluation of silk moth (Bombyxmori) allergens in sericulture grainage industries as major pollutants.Journal of Scientific and Industrial Research.Vol. 64. pp. 287-292.

Wang, X. R., Eisen, E.A., Zhang, H. X., Sun, B. X., Dai, H.L., Pan, L.D., Wegman, D.H., Olenchock, S.A., Christiani, D.C., 2003. Respiratory symptoms and cotton dust exposure; Results of 15 year follow up observation; occupational and Environmental Medicine, 60, pp. 935 941.

Wen, CM, Ye, ST, Zhou, LK and Yu, Y., 1999. Silk - induced asthma in children. A report of 64 cases, Ann. Allergy, 65, pp. 375378. 